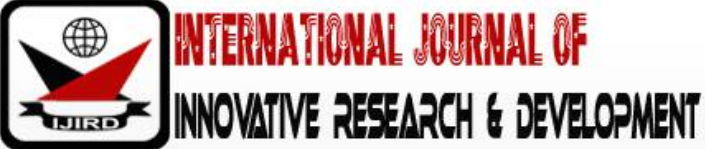

ISSN 2278-0211 (Online)

\section{Physico-Chemical Characterization of an Urban Hydrosystem (Ebolowa Municipal Lake, South-Cameroon): Application of the Principal Component Analysis (PCA) for the Water Typology Identification}

Ghislaine Madjiki-Adjia
Research Assistant, Hydrological Research, Centre (CRH) of the Institute for Geological
and Mining Research (IRGM), Cameroon
Annie-Claude Pial
Lecturer, Department of Plant Biology, University of Yaounde I, Cameroon
Henriette Ateba-Bessa
Research Officer, Laboratory of Geochemical, Water Analysis (LAGE), Hydrological
Research Centre (CRH), Institute for Geological and Mining Research (IRGM), Cameroon
Gloria Eyong
Senior Research Officer, Hydrological Research Centre (CRH), Institute for Geological
and Mining Research (IRGM), Cameroon

\begin{abstract}
:
This study was carried out in order to characterize on the physico-chemical level the waters of Ebolowa Municipal Lake. To study this hydrosystem, three sampling sites (S1, S2 and S3) were monitored throughout a seasonal cycle, to identify the lake water typology based on the characteristics of effluents discharged in to it. Fifteen parameters were measured in the field and in the laboratory on the three sites. The results obtained have been subject to multi-variate statistical treatment via the Principal Component Analysis (PCA), and revealed that sampling sites S1 and S3 are the most polluted, while site S2 shows moderate pollution. Three distinct water typology groups were highlight: the first one corresponding to waters of site S1, is the group of water rich in organic matter; the second one, group of mineralized, deep and oxygen rich waters correspond to waters of site $S 2$; and the last one corresponding to waters of site $S 1$ is the group of turbid waters rich in suspended matters. The anthropic activities developing near this water body are undoubtedly the cause of this pollution.
\end{abstract}

Keywords: Water quality, physico-chemical analysis, principal component analysis, water typology, ebolowa municipal lake

\section{Introduction}

The degradation of surface water quality is one of the major environmental problems facing humanity. Freshwater resources such as rivers, lakes, reservoirs and wetlands are being degraded around the world as a result of pollution from point and non-point sources 'Zalewski and Wagner-Lotkowska, 2002 ; Adjia et al., 2013". Numerous studies have been carried out on the effects of industrial and urban discharges on the evolution of surface water quality and the pollution of continental aquatic ecosystems 'Reggam et al., 2015". Human activities (industrial and agricultural activities, etc.) are some of the main causes of surface water pollution and the origin of stress in aquatic ecosystems 'Njine et al., 2007". In recent years, many African countries have experienced a rapid increase in population accompanied by unplanned urbanization and intensive industrial and agricultural developments. All this has led to an increase in the flow of effluent discharged into water bodies, having undesirable effects on the various components of the aquatic environment. Many water bodies have already been irreversibly damaged, particularly those located near large human settlements 'Zohary et al., 1996". In Cameroon, several point sources of pollution have been identified but, considering the whole country, the main problems of water pollution seem to be mainly due to the lack of a real waste management strategy, with the consequence of the inexistence of sewerage systems. This institutional failure is coupled in the large cities with the incivility of the population, who constantly deposit waste from all human activities in to the aquatic environment. This situation has resulted in the pollution of urban water bodies, particularly lakes, whose multiple roles (recreational, touristic, cultural and aesthetic) have been altered, leading to the loss of social and economic benefits 'Ridhi and Garg, 2015". In the capital city Yaounde, several lakes and ponds are endangered due to anthropogenic eutrophication. 
The case of the Yaounde Municipal Lake no longer need to be demontrated. Since the beginning of 1980's, this hydrosystem is undergoing a strong agression due to untreated effluent discharge into it 'Njine et al., 2007". The Ebolowa Municipal Lake (EML) is a case in point. Situated in the capital of the south region of Cameroon, the EML serves as a waste dump for garbage and waste water from riverside households; for the Central Market (CM) and the Ebolowa Regional Hospital (ERH). Considering the large pollution load, there is no doubt that this aquatic ecosystem is disturbed. In the early 2000 's, this lake has been experiencing a notable degradation of the physico-chemical and biological quality of its waters 'Ewane, 2005".

The present work, based on the multivariate analysis, aims to characterize the EML waters at the physicochemical level. Specifically it is more about : (1) to carry out a physico-chemical analysis of the lake waters ; (2) to bring out the typology of the lake waters, this by applying the Principal Component Analysis (PCA).

\section{Materials and Methods}

\subsection{Présentation of the Study Area}

Ebolowa Municipal Lake (Fig. 1) is an artificial lake, created in 1962 on the courses of two rivers, Mfoumou River and Bengo'o River 'Ewane, 2005". Initially developed for water sports, fish farming and tourism, the lake was abandoned for a long time, although artisanal fishing continued to be carried out. At the present, some recreational activities (boat trips, swimming, fishing, etc) are being around the lake.

The study area is located in the humid equatorial domain, which is under the influence of the 'Guinean' climate. This climate is divided into four seasons : a long rainy season from mid-March to mid-July ; a short rainy season from midAugust to mid-November ; a long dry season from mid-November to mid-March ; and a short dry season from mid-July to mid-August. Annual rainfall in the area varies between 1500 and $2000 \mathrm{~mm}$, with an annual temperature range of $2^{\circ} \mathrm{C}$, for an average temperature of $25^{\circ} \mathrm{C}$ 'ERA-Cameroun, 2007". This reservoir, whose surface area decrease over the years $(16$ ha in 2005 for 13.25 ha in 2013), is located between the Angale, Nko'ovos I and Ekombite districts behind the Ebolowa Regional Hospital (Fig. 1). In the NNW direction, it receives water from the Mfoumou River on the side of central market; while the Bengo'o River flows in to the lake in the NNE direction. The outlet of this lake is a concrete structure that connects the city centre to the Angale district 'Adjia et al., 2013; Ewane, 2005".

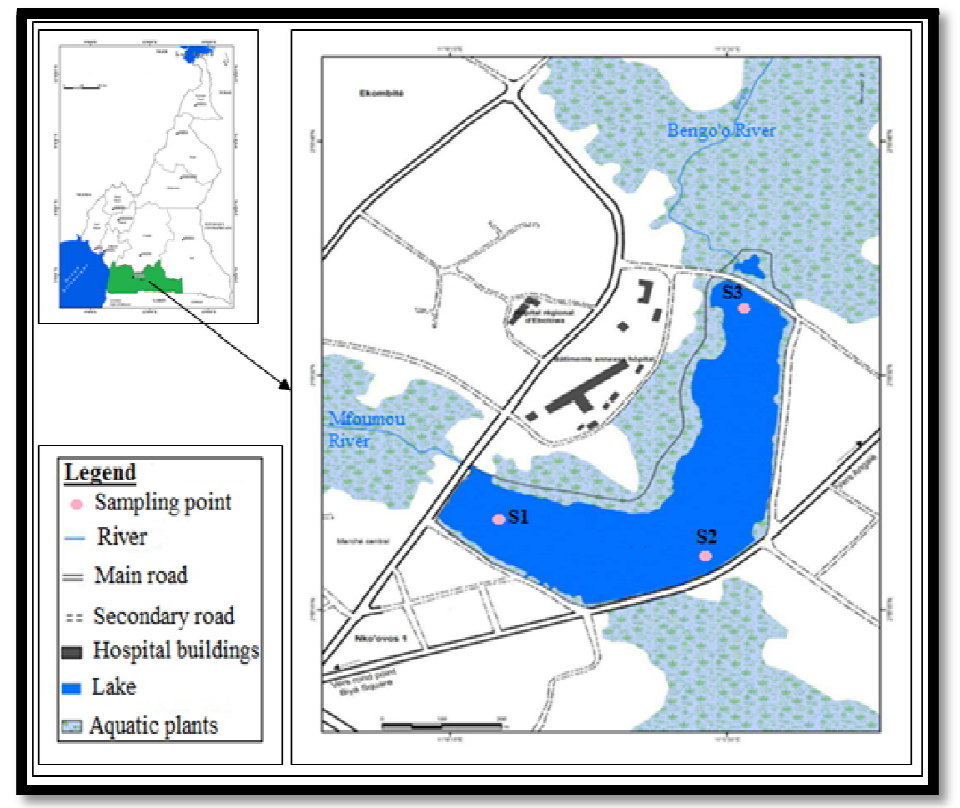

Figure 1: The Study Area and the Sampling Sites

\subsection{Sampling and Field Measurements}

Sampling was done based on the arc shape nature of the lake and also its recharge. To ensure a better coverage of the study area, three sampling sites were selected (Table 1 ; Fig. 1).

\begin{tabular}{|c|c|c|c|}
\hline Site & GPS Coordinate & Elevation (m) & Description \\
\hline S1 & $02^{\circ} 55.343^{\prime} \mathrm{N} ; 011^{\circ} 09.290^{\prime} \mathrm{E}$ & 581 & $\begin{array}{c}\text { Located at few meters from the entrance of the } \\
\text { Mfoumou River into the lake. }\end{array}$ \\
\hline S2 & $02^{\circ} 55.312^{\prime} \mathrm{N} ; 011^{\circ} 09.478^{\prime} \mathrm{E}$ & 576 & $\begin{array}{c}\text { Located more or less at the center of the lake, at } \\
\text { few meters of its outlet. }\end{array}$ \\
\hline S3 & $02^{\circ} 55.573^{\prime} \mathrm{N} ; 011^{\circ} 09.217^{\prime} \mathrm{E}$ & 578 & $\begin{array}{c}\text { Located at few meters from the entrance of the } \\
\text { Bengo'o River into the lake. }\end{array}$ \\
\hline
\end{tabular}

Table 1: Georeferenced Position and Description of Sampling Sites

Source 'Adjia et al., 2013" 
Fifteen physico-chemical parameters were measured in the field and/or in the laboratory, this at the three selected sampling sites. Sampling was carried out on a bi- monthly basis, from February to September 2012, in order to cover all the four seasons. Sampling was done on the surface and at $0.5 \mathrm{~m}$ depth, as indicated for shallow lakes 'Izydorczyk, 2004". Temperature (Temp), Transparency (Tra) and Depth (Dep) were measured in the field. Water samples for physicochemical analysis were collected using the labelled 1L PVC bottles. At each sampling site, the bottles were rinsed three time with the water to be analysed before sampling. The samples for analysis were then transported in a cooler, to the Waste Water Research Unit of the Plant Physiology Laboratory of the University of Yaounde I.

\subsection{Laboratory Analysis}

The physico-chemical analysis methods described by the Afnor standards on 'Water quality', those of Rodier on 'Water analysis' and APHA 'A.F.N.O.R., 1997 ; Rodier, 2009; A.P.H.A., 1998" are those used in this study for laboratory analysis. The following physico-chemical parameters were analysed in the laboratory : Hydrogen Potential ( $\mathrm{pH})$, Electrical Conductivity (EC), Turbidity (Tur), Total Dissolved Solids (TDS), Suspended Matters

(SM), Dissolved Oxygen (DO), Dissolved Organic Carbon (DOC), Nitrites $\left(\mathrm{NO}_{2}{ }^{-}\right)$, Nitrates $\left(\mathrm{NO}_{3}{ }^{-}\right)$, Ammonium $\left(\mathrm{NH}_{4}{ }^{+}\right)$, Ortho-phosphates $\left(\mathrm{PO}_{4}{ }^{3-}\right)$, Silica $\left(\mathrm{SiO}_{2}\right)$. All the equipment used for analysis were previously calibrated 'A.F.N.O.R., 1997; Rodier, 2009". Table 2 gives a summary of the physico-chemical parameters analysed, their units and the analysis method used.

\begin{tabular}{|c|c|c|c|}
\hline Parameters & Abbreviations & Units & Analytical Method \\
\hline Temperature & Tem & ${ }^{\circ} \mathrm{C}$ & Electrometry \\
\hline $\mathrm{pH}$ & $\mathrm{pH}$ & $\mathrm{pH} \mathrm{Units}$ & Electrometry \\
\hline Electrical Conductivity & $\mathrm{EC}$ & $\mu \mathrm{Scm}{ }^{-1}$ & Conductivity meter \\
\hline Turbidity & $\mathrm{Tur}$ & $\mathrm{FNU}$ & Turbidity meter \\
\hline Transparency & $\mathrm{Tra}$ & $\mathrm{cm}$ & Secchi disk \\
\hline Depth & $\mathrm{Dep}$ & $\mathrm{cm}$ & Secchi disk \\
\hline Total Dissolved Solids & $\mathrm{TDS}$ & $\mathrm{mg} \cdot \mathrm{L}^{-1}$ & Spectrophotometric \\
\hline Suspended Matters & $\mathrm{SM}$ & $\mathrm{mg} \cdot \mathrm{L}^{-1}$ & Spectrophotometric \\
\hline DissolvedOxygen & $\mathrm{DO}$ & $\mathrm{mg} \cdot \mathrm{L}^{-1}$ & Winkler method \\
\hline Dissolved Organic Carbon & $\mathrm{DOC}$ & $\mathrm{mg} \cdot \mathrm{L}^{-1}$ & Titrimetric method \\
\hline Nitrites & $\mathrm{NO}_{2}{ }^{-}$ & $\mathrm{mg} \cdot \mathrm{L}^{-1}$ & UV Spectrophotometric method \\
\hline Nitrates & $\mathrm{NO}_{3}{ }^{-}$ & $\mathrm{mg} \cdot \mathrm{L}^{-1}$ & UV Spectrophotometric method \\
\hline Ammonium & $\mathrm{NH}_{4}{ }^{+}$ & $\mathrm{mg} \cdot \mathrm{L}^{-1}$ & UV Spectrophotometric method \\
\hline Ortho-phosphates & $\mathrm{PO}_{4}{ }^{3-}$ & $\mathrm{mg} \cdot \mathrm{L}^{-1}$ & UV Spectrophotometric method \\
\hline Silica & $\mathrm{SiO}_{2}$ & $\mathrm{mg} \cdot \mathrm{L}^{-1}$ & Colorimetric method \\
\hline
\end{tabular}

Table 2: Physico-Chemical Parameters, Abbreviation, Unit and Analysis Method

\subsection{Data Processing and Principal Component Analysis (Pca)}

The Principal Component Analysis (PCA) is a multi-variate analysis method allowing the simultaneous study of a large number of variables, whose total information cannot be viewed because of a space of more than three dimensions. With the aim of concentrating the information on a minimum number of axes 'Mouissi and Alayat, 2016; Ayadi et al., 2008 ", the PCA provides information on the most significant parameters describing the data set, and summarizes the statistical correlations between these parameters with minimal loss of original information 'Ridhi and Garg, 2015". Widely used for hydro-chemical data interpretation 'Abrid, 2015", this method would allow to highlight the relationships between the variables and the phenomena behind these relationships. PCA is therefore a tool that has the potential to simplify the study of aquatic ecosystems and reduce costs by reducing the number of variables to be taken in account 'Mouissi and Alayat, 2016". In this study, statistical analysis of the physico-chemical data was performed on a data matrix of 15 parameters distributed over three sampling sites. PCA made it possible to highlight the interrelationships between the physico-chemical parameters of the EML waters, as well as their distribution in the three (03) sampling sites. The RStudio interface of the statistical analysis software R was used for the statistical calculations 'Husson et al., 2009", as well as for the Principal Component Analysis (PCA) 'Lê et al., 2008”.

\section{Results And Discussion}

\subsection{Main Sources of Water Pollution in Ebolowa's Municipal Lake (EML)}

The field observations have shown the existence of several activities developing near of the EML and highly contributing to the pollution of the lake (Fig. 2). The presence of the Central market (CM), the Ebolowa's Regional hospital (ERH) and the riverside houses nearby the LME undoubtedly drain wastewaters into this watercourse. In addition to this situation, there are uncontrolled garbage dumps, car washing and the use of fertilizers for crops (lettuce, nightshade...) close of this hydrosystem. As a result of the increasing occupation of the surrounding space, all these urban discharges unfortunately end up in the lake, and there is a visible degradation of the quality of its waters. 


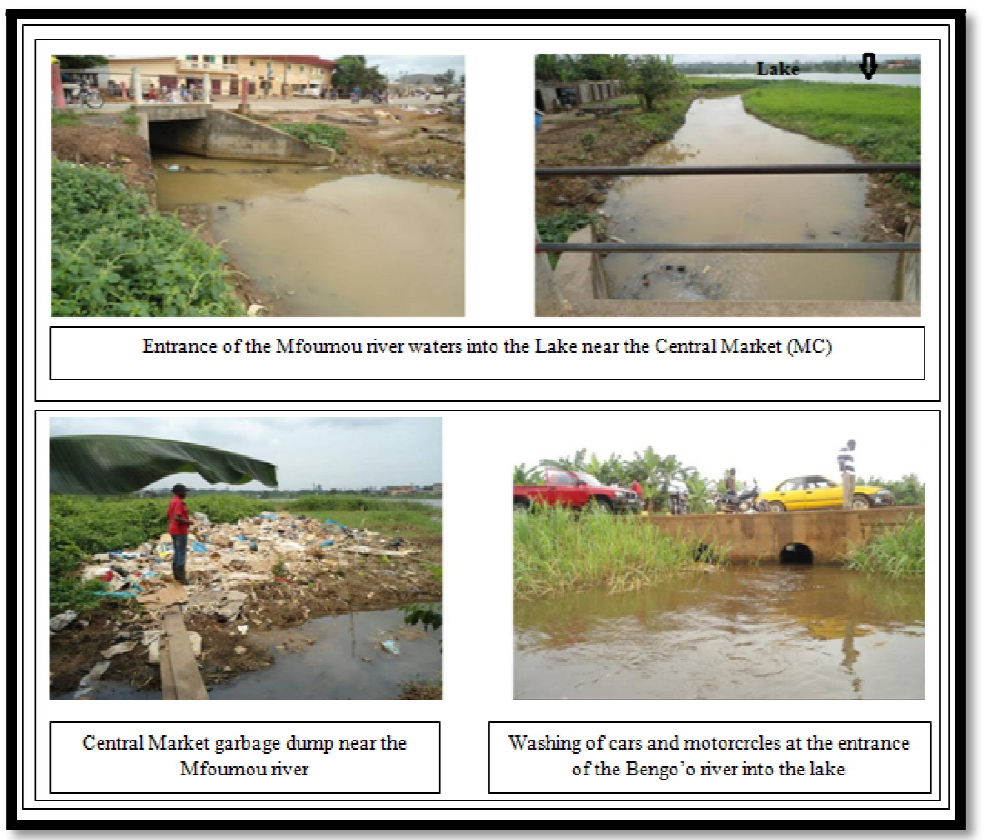

Figure 2: Inventory of A Few Sites near the Ebolowa Municipal Lake (EML)

\subsection{Physico-Chemical Characterization of EML Waters}

The physico-chemical indicators of water quality, are often subject to spatial and temporal variations induced by anthropogenic activities that modify the water characteristics and affect its quality. Thus, measurements of these parameters in a hydrosystem can provide informations on the waters pollution degree of this aquatic ecosystem 'Reggam et al., 2015". The results of the physico-chemical analysis of EML waters are presented in Table 3.

Temperature (Tem) is an essential parameter in the water quality assessment and is one of the important factors controlling almost all the physico-chemical and biological reactions in aquatic environments 'Ayah et al., 2015; Chapman and Kimstach, 1996". EML water's temperature shows slight vatiations for the three sampling sites (S1, S2 and S3). Mean temperature values range from $\left(25.18 \pm 0.72^{\circ} \mathrm{C}\right)$ at sampling site $\mathrm{S} 1,\left(25.09 \pm 0.87^{\circ} \mathrm{C}\right)$ at site $\mathrm{S} 2$ and $\left(24.89 \pm 1.00^{\circ} \mathrm{C}\right)$ at $s i t e$ S3. The shallow depth of the lake ensures that the water temperature in this lake remains more or less homogeneous throughout the thickness of the water slice. These results are in line with two others studies carried out respectively at the Yaounde Municipal Lake 'Njine et al., 2007 ; Kemka and al., 2003" and at the Mopfou Dam 'Djoko, 2007”, which showed that at the epilimnion level of these water bodies, temperature variations are very small.

\begin{tabular}{|c|c|c|c|c|c|c|c|c|c|c|c|c|}
\hline & \multicolumn{9}{|c}{ S1 } & \multicolumn{4}{c|}{ S2 } & \multicolumn{4}{c|}{ S3 } \\
\hline & Min & Max & Mean & Sd & Min & Max. & Mean & Sd & Min. & Max. & Mean & Sd \\
\hline $\mathrm{Tem}$ & 24.00 & 26.20 & 25.18 & 0.72 & 23.10 & 25.90 & 25.09 & 0.87 & 22.85 & 26.00 & 24.89 & 1.00 \\
\hline $\mathrm{pH}$ & 6.71 & 7.35 & 6.97 & 0.19 & 6.89 & 7.38 & 7.06 & 0.16 & 6.40 & 7.40 & 6.78 & 0.39 \\
\hline $\mathrm{CE}$ & 127.35 & 357.45 & 282.91 & 78.41 & 124.85 & 359.35 & 281.29 & 77.85 & 120.85 & 353.55 & 278.96 & 77.18 \\
\hline Tur & 25.50 & 59 & 46.06 & 10.95 & 46.00 & 69.5 & 55.69 & 6.60 & 58.50 & 65.50 & 62.00 & 2.44 \\
\hline Tra & 20.00 & 40.00 & 30.50 & 7.15 & 38.00 & 49.00 & 40.88 & 3.60 & 28.00 & 63.00 & 43.38 & 14.24 \\
\hline Dep & 44.50 & 80.00 & 66.44 & 12.78 & 100.00 & 142.00 & 119.44 & 13.80 & 50.00 & 110.50 & 73.38 & 21.73 \\
\hline TDS & 28.25 & 97.45 & 58.23 & 24.70 & 25.46 & 83.35 & 46.29 & 20.20 & 16.95 & 69.55 & 33.43 & 17.09 \\
\hline $\mathrm{SM}$ & 16.50 & 38.00 & 25.84 & 6.62 & 8.00 & 47.00 & 24.86 & 11.99 & 5.00 & 17.50 & 13.06 & 3.94 \\
\hline $\mathrm{DO}$ & 1.10 & 2.40 & 1.71 & 0.48 & 1.20 & 3.00 & 2.49 & 0.57 & 0.70 & 1.90 & 1.22 & 0.44 \\
\hline $\mathrm{DOC}$ & 8.66 & 22.80 & 12.31 & 4.75 & 5.14 & 17.50 & 8.86 & 4.10 & 9.10 & 27.00 & 16.43 & 6.58 \\
\hline $\mathrm{NO}_{2}{ }^{-}$ & 0.00 & 0.07 & 0.02 & 0.02 & 0.00 & 0.06 & 0.01 & 0.02 & 0.00 & 0.06 & 0.01 & 0.02 \\
\hline $\mathrm{NO}_{3}{ }^{-}$ & 0.20 & 6.40 & 3.04 & 2.02 & 0.00 & 8.90 & 3.61 & 2.80 & 0.00 & 7.00 & 3.74 & 2.50 \\
\hline $\mathrm{NH}_{4}{ }^{+}$ & 0.71 & 2.61 & 1.50 & 0.64 & 0.53 & 1.84 & 1.07 & 0.37 & 0.50 & 1.47 & 0.85 & 0.38 \\
\hline $\mathrm{PO}_{4}{ }^{3-}$ & 0.11 & 1.24 & 0.58 & 0.37 & 0.03 & 0.47 & 0.22 & 0.16 & 0.10 & 1.24 & 0.36 & 0.36 \\
\hline $\mathrm{SiO}_{2}$ & 1.30 & 3.40 & 2.71 & 0.72 & 0.80 & 2.90 & 2.23 & 0.69 & 1.20 & 3.20 & 2.40 & 0.84 \\
\hline
\end{tabular}

Table 3: Summary of the Physico-Chemical Parameters Analysed at the EML (Minimum and Maximum Values, Mean and Standard Deviation) According to the Sampling Sites

The Hydrogen Potential $(\mathrm{pH})$ measures the concentration of hydronium ions $(\mathrm{H}+)$, and results from the mobilization of the carbon dioxide by the water photosynthetic activity 'Adjia et al., 2013". The mean pH values of the EML range from $(6.97 \pm 0.19)$ for site S1, $(7.06 \pm 0.16)$ for site S2 and $(6.78 \pm 0.39)$ for site S3. The season has an influence on the the water $\mathrm{pH}$ because during the rainy season for example, there is dilution of the different ions in the water leading to a decrease in $\mathrm{pH}$ values. These values, which fluctuate around neutrality, indicate that EML waters are slightly acidic to slightly alkaline 'Madjiki, 2013". 
Electrical conductivity (EC) refers to the ability of water to conduct electricity. Mean EC values at the EML varied from (282.92 $\pm 78.41 \mu \mathrm{S} . \mathrm{cm}-1)$ for site S1, (281.29 $\pm 77.85 \mu \mathrm{S} . \mathrm{cm}-1)$ for site S2 and (278.96 $\pm 77.18 \mu \mathrm{S} . \mathrm{cm}-1)$ for site S3. The minimum values are obtained during the rainy season, a consequence of the ions dilution in solution and also because the effluents pourred in to the lake contained organic matters known for their ability to change the conductivity 'Stodddard et al., 1999". From the EC values obtained, we can say that EML waters are moderately mineralized, this because in the aquatic environment the EC is proportional to the water mineralization degree 'Madjiki, 2013".

Turbidity is the measure of the more or less turbid aspect of the water. Closely related to water transparency, which evaluates the depth of disappearance of a white Secchi disc in the water, turbidity is caused by the presence in the water of various particulate or colloidal materials composed of silts, clays, organic or inorganic compounds as well as plankton and other microorganisms. The mean turbidity values for the three sampling sites are (46.06 $\pm 10.95 \mathrm{FNU}$ ) for $\mathrm{S} 1$; $(55.69 \pm 6.60 \mathrm{FNU})$ for S2 and $(62.00 \pm 2.45 \mathrm{FNU})$ for S3. These turbidity values vary according to the sampling site with a minimum value of $25.50 \mathrm{FNU}$ and a maximum value of $69.50 \mathrm{FNU}$ for the lake taken as a whole.

The transparency of the EML does not exceed $65 \mathrm{~cm}$ for the three sampling sites. The mean transparency value for the lake as a whole is $(38.25 \pm 10.66 \mathrm{~cm})$, with extreme values of $20.00 \mathrm{~cm}$ and $63.00 \mathrm{~cm}$ respectively.

Depth values recorded in the field ranged from 44.50 to $80.00 \mathrm{~cm}$ for the sampling site S1; 100.00 to $142.00 \mathrm{~cm}$ for site S2 and 50.00 to $110.50 \mathrm{~cm}$ for site S3. The average depth value for the lake is about $(86.42 \pm 28.79 \mathrm{~cm})$.

These results show that the sampling site S2 is the one presenting the highest depth values, this probably because of its position more or less in the centre of the lake, quite far from the various sources of pollution of this water body.

TDS represents the total concentration of dissolved solids in the water, often composed of inorganic salts and some organic matters. Average TDS values in EML waters are quite low for all the three sampling sites. These values are of (58.23 \pm 24.70 mg.L-1) for site S1, (46.29 \pm 20.20 mg.L-1) for site S2 and (33.43 \pm 17.09 mg.L-1) for site S3.

SM originates from mineral and organic particles washed by rain erosion and carried by water, or re-suspended during water recirculation phenomena. Throughout the sampling period, sampling sites S1 and S2 had the highest values of SM. The mean concentrations for the three sites are (25.84 $\pm 6.62 \mathrm{mg}$.L-1) for site S1 ; $(24.88 \pm 12.00 \mathrm{mg} . \mathrm{L}-1)$ for site S2 and (13.06 \pm 3.94 mg.L-1) for site S3. The average value for the lake is of about (21.26 $\pm 9.85 \mathrm{mg} . \mathrm{L}-1)$. The low levels of TDS and SM at the sampling site S3 can be explained by the fast circulation of the Bengo'o River waters as it enter the EML, thus preventing the deposition of these materials near the sampling site.

Dissolved oxygen (DO) is one of the most important parameters in water quality assessment, as it affects the survival and distribution of aquatic flora and fauna. DO content is important for the needs of many organisms because it affects the solubility of many nutrients, as well as the productivity of the aquatic ecosystem 'Ridhi and Garg, 2015; Wetzel, 1983". D0 in surface waters comes from the atmosphere and the photosynthetic activity of aquatic plants 'Arrignon, 1991". In EML, the average DO content is of $(1.71 \pm 0.48 \mathrm{mg}$. L-1) for site S1; $(2.49 \pm 0.57 \mathrm{mg} . \mathrm{L}-1)$ for site $\mathrm{S} 2$ and $(1.22 \pm 0.44$ mg.L-1) for site S3. The lake waters appears to be oxygenated however, the very low DO levels for all the three sampling sites indicates the poor quality of the water. As a matter of fact, when the dioxygen (02) concentration is below $2.00 \mathrm{mg}$. $\mathrm{L}-$ 1 (as in the case for sites S1 and S3), many aquatic organisms die as a result of the decomposition processes that reduced DO levels 'Cunningham and Saigo, 1997". The low DO levels observed at these two sampling sites in particular may be assigned to effluents discharged by riverine populations in to the Mfoumou and the Bengo'o rivers located near these two sites and which supplied the LME.

Closely related to the DO content, the Dissolved Organic Carbon (DOC) content go in the opposite direction to that of DO because, during the photosynthesis process, carbon dioxide (CO2) is consumed and dioxygen (02) is released. The mean DOC values for the the three sampling sites are of (12.31 $\pm 4.71 \mathrm{mg}$. L- 1$)$ for site S1, (8.86 $\pm 4.10 \mathrm{mg} . \mathrm{L}-1)$ for site S2 and (16.43 $\pm 6.58 \mathrm{mg} . \mathrm{L}-1)$ for site S3.

Nitrite ions $\left(\mathrm{NO}_{2}^{-}\right)$comes from incomplete oxidation of ammonia or reduction of nitrate $\left(\mathrm{NO}_{3}^{-}\right)$by denitrifying bacteria. The average $\mathrm{NO}_{2}^{-}$levels in the EML waters are low and are of (0.02 $\pm 0.02 \mathrm{mg}$. L-1) for site S1, (0.01 $\pm 0.02 \mathrm{mg} . \mathrm{L}-$ 1) for sites $S 2$ and $S 3$.

Nitrogen water pollution can be estimated by measuring nitrate $\left(\mathrm{NO}_{3}{ }^{-}\right)$and ammonium $\left(\mathrm{NH}_{4}{ }^{+}\right)$ions in water. $\mathrm{NO}_{3}{ }^{-}$ions represent the most soluble form of nitrogen, its presence in surface waters is linked to the intensive use of chemical or organic fertilizers 'Njine et al., 2007 ; Lgourna et al., 2014". The average concentrations of $\mathrm{NO}_{3}{ }^{-}$in the lake varies between $(3.04 \pm 2.02 \mathrm{mg}$. L-1) for the S1 site, (3.61 $\pm 2.80 \mathrm{mg}$.L-1) for the S2 site and (3.74 $\pm 2.50 \mathrm{mg}$.L-1) for the S3 site. The agricultural activities carried out by the riverside populations could be able to explain the observed concentrations of nitrate in the lake waters.

Coming from anaerobic conditions in ecosystems, the ammonium $\left(\mathrm{NH}_{4}^{+}\right)$ion is the main form of nitrogen in the nature 'Njine et al., 2007". At the LME, the mean concentrations of $\mathrm{NH}_{4}{ }^{+}$range from $(1.50 \pm 0.64 \mathrm{mg} . \mathrm{L}-1)$ for point S1, (1.07 \pm 0.37 mg.L-1) for point S2 and (0.85 $\pm 0.38 \mathrm{mg}$.L-1) for point S3.

Phosphorus is one of the most important biogenic elements in nature, essential for the growth of algae, bacteria and protozoa 'El Oumlouki et al., 2014". Eutrophication problems in water start when the concentrations of this element range from 0.34 to $0.70 \mathrm{mg} . \mathrm{L}-1$ 'Ayah et al., 2015" On the EML, mean concentrations of ortho-phosphates ( $\left.\mathrm{PO}_{4}{ }^{3-}\right)$ are higher at sites S1 (0.58 $\pm 0.37 \mathrm{mg} . \mathrm{L}-1)$ and S3 $(0.36 \pm 0.36 \mathrm{mg} . \mathrm{L}-1)$ compared to site $\mathrm{S} 2(0.22 \pm 0.16 \mathrm{mg} . \mathrm{L}-1)$. This is the consequence of the activities carried out by riverine populations of the two rivers that supply the lake. The use of fertilizers for crop cultivation is a common practice in the area where the Mfoumou River waters enters in to the lake. Coupled to household waste dumps and waste from the CM, these could probably be the origin of the degradation of water quality at the sampling site S1. At site S3, effluents from the ERH and the intense vehicles washing activities in the Bengo'o River could be the source of pollutant enrichment (particularly phosphates) of water at this site. This could explain the intense proliferation of macrophytes at sites S1 and S3. It also explains the presence of particular phytoplanktonic groups 
which are characteristic of eutrophic to hyper-eutrophic waters such as the Cyanobacteria (blue-green algaes) present in this lake 'Madjiki, 2013".

Variations in silica (SiO2) fluxes are dependent on lithology, erosion rate, climate and diatoms production 'Mouissi and Alayat, 2016". In EML, SiO2 levels are relatively low (2.71 $\pm 0.72 \mathrm{mg}$. L-1) for site S1 ; $2.23 \pm 0.69 \mathrm{mg}$.L-1) for site S2 and (2.40 $\pm 0.84 \mathrm{mg} . \mathrm{L}-1)$ for site S3. Although sites S1 and S3 have the highest mean concentrations. The low values of SiO2 at the EML can be explained by the intense assimilation of this element by Diatoms, a large phytoplanktonic group present in this lake "Madjiki, 2013".

\subsection{Principal Component Analysis (PCA)}

The Pearson's Correlation Coefficient was used in order to determine the relationships between the fifteen water quality parameters of the EML. The study of the linear bi-variate correlations between the studied parameters, provides information on the strength of possible associations between them 'Benchaar, 1999'. Correlation matrix of the 15 parameters is presented in Table 4. Significant and positive correlations are observed between Tem and EC $(r=0.53)$; Tem and $\mathrm{SiO}_{2}(\mathrm{r}=0.50)$; $\mathrm{pH}$ and EC $(\mathrm{r}=0.51)$; EC and TDS $(\mathrm{r}=0.50)$; Tur and Tra $(\mathrm{r}=0.52)$; Dep and DO $(\mathrm{r}=0.57)$; TDS and SM $(r=0.65)$; TDS and $\mathrm{NH}_{4}{ }^{+}(\mathrm{r}=0.66)$ and between DOC and $\mathrm{NO}_{2}{ }^{-}(\mathrm{r}=0.50)$.

\begin{tabular}{|c|c|c|c|c|c|c|c|c|c|c|c|c|c|c|c|}
\hline & Tem & $\mathrm{pH}$ & EC & Tur & Tra & Dep & TDS & SM & DO & DOC & $\mathrm{NO}_{2}^{-}$ & $\mathrm{NO}_{3}{ }^{-}$ & $\mathrm{NH}_{4}{ }^{+}$ & $\mathrm{PO}_{4}{ }^{3-}$ & $\mathrm{SiO}_{2}$ \\
\hline Tem & $r$ & & & & & & & & & & & & & & \\
\hline $\mathrm{pH}$ & $\begin{array}{l}8 \\
0 \\
0\end{array}$ & $-r$ & & & & & & & & & & & & & \\
\hline $\mathrm{EC}$ & 艿 & 로 & - & & & & & & & & & & & & \\
\hline Tur & $\begin{array}{l}\text { J } \\
0 \\
i\end{array}$ & $\begin{array}{l}\text { ò } \\
\text { i. }\end{array}$ & $\stackrel{\infty}{\circ}$ & - & & & & & & & & & & & \\
\hline Tra & $\begin{array}{l}0 \\
0 \\
0\end{array}$ & $\begin{array}{l}0 \\
0 \\
0 \\
i\end{array}$ & $\begin{array}{l}m \\
0 \\
0\end{array}$ & กิ & $\neg$ & & & & & & & & & & \\
\hline Dep & $\begin{array}{l}\text { ț } \\
\dot{0}\end{array}$ & $\begin{array}{l}\infty \\
0 \\
0\end{array}$ & $\begin{array}{l}\text { Oे } \\
0 \\
0\end{array}$ & $\stackrel{0}{0}$ & $\stackrel{\sigma}{0}$ & $r$ & & & & & & & & & \\
\hline TDS & ֻొ & $\stackrel{\infty}{\stackrel{\infty}{0}}$ & ํㅗㅁ & $\begin{array}{l}\hat{0} \\
0 \\
\end{array}$ & $\stackrel{\sim}{0}$ & $\begin{array}{l}0 \\
0 \\
0 \\
1\end{array}$ & -1 & & & & & & & & \\
\hline SM & $\stackrel{8}{0}$ & $\stackrel{\widetilde{m}}{\tilde{\sigma}}$ & $\stackrel{\infty}{\stackrel{0}{0}}$ & $\begin{array}{l}\infty \\
0 \\
0\end{array}$ & ने & $\stackrel{\infty}{\stackrel{\infty}{0}}$ & : & - & & & & & & & \\
\hline$\overline{\text { DO }}$ & $\begin{array}{l}0 \\
0 \\
0\end{array}$ & नें & $\begin{array}{l}0 \\
\text { O̊ } \\
\text { ị }\end{array}$ & ㄱ: & $\stackrel{\vec{t}}{\circ}$ & นิำ & $\vec{m}$ & 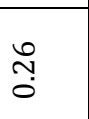 & - & & & & & & \\
\hline DOC & $\begin{array}{l}\text { H. } \\
\text { i }\end{array}$ & $\begin{array}{l}\stackrel{+}{m} \\
\stackrel{i}{i}\end{array}$ & $\begin{array}{c}\tilde{n} \\
\stackrel{1}{1}\end{array}$ & $\begin{array}{l}m \\
0 \\
0\end{array}$ & $\stackrel{m}{\stackrel{m}{0}}$ & $\begin{array}{l}0 \\
\text { m. } \\
\text { ị }\end{array}$ & $\begin{array}{c}\infty \\
\text { m. } \\
\stackrel{i}{i}\end{array}$ & $\begin{array}{l}m \\
m \\
\stackrel{m}{i}\end{array}$ & 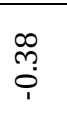 & $r$ & & & & & \\
\hline $\mathrm{NO}_{2}^{-}$ & \begin{tabular}{l}
\multirow{b}{0}{} \\
i.
\end{tabular} & $\begin{array}{l}m \\
m \\
0 \\
i\end{array}$ & $\begin{array}{l}8 \\
\$ \\
0 \\
1\end{array}$ & \begin{tabular}{l} 
Oे \\
\hdashline \\
\end{tabular} & $\begin{array}{l}m \\
0 \\
i \\
i\end{array}$ & $\begin{array}{l}-1 \\
0 \\
i\end{array}$ & ָ̊. & $\begin{array}{l}\text { Õ } \\
\stackrel{0}{0}\end{array}$ & సี. & นึ & $r$ & & & & \\
\hline $\mathrm{NO}_{3}^{-}$ & $\stackrel{\infty}{\dddot{0}}$ & ठ艹 & $\stackrel{\circ}{0}$ & $\stackrel{\sim}{\stackrel{2}{0}}$ & $\stackrel{m}{0}$ & . & $\stackrel{\text { I̊ }}{\text { ஸे }}$ & , İ & 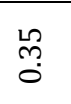 & , $\stackrel{\infty}{m}$ & , & $-r$ & & & \\
\hline $\mathrm{NH}_{4}{ }^{+}$ & $\begin{array}{l}\text { ñ } \\
\text { ○े }\end{array}$ & $\begin{array}{l}+ \\
0 \\
0\end{array}$ & $\stackrel{1}{\stackrel{0}{0}}$ & $\begin{array}{l}\text { N̦} \\
\stackrel{i}{i}\end{array}$ & ج্ণ & $\begin{array}{l}0 \\
\stackrel{1}{0} \\
i\end{array}$ & $\begin{array}{l}0 \\
\stackrel{0}{0}\end{array}$ & $\stackrel{\hat{m}}{0}$ & 웅 & $\begin{array}{c}m \\
m \\
\stackrel{m}{i}\end{array}$ & $\begin{array}{l}\text { L } \\
0 \\
\stackrel{0}{0}\end{array}$ & $\stackrel{\vec{m}}{0}$ & $\neg$ & & \\
\hline $\mathrm{PO}_{4}{ }^{3-}$ & $\stackrel{\text { L }}{\stackrel{0}{0}}$ & 웅 & $\stackrel{\stackrel{H}{J}}{0}$ & 궁 & $\begin{array}{l}0 \\
\text { m. } \\
\text { i }\end{array}$ & $\begin{array}{c}\text { m̃ } \\
\text { ô } \\
\end{array}$ & $\stackrel{\text { ָ̦ }}{\text { Oे }}$ & m্. & $\begin{array}{l}\text { फी } \\
\text { in }\end{array}$ & $\begin{array}{l}\infty \\
0 \\
0\end{array}$ & $\begin{array}{c}\hat{N} \\
\text { ị }\end{array}$ & $\begin{array}{l}\text { in } \\
\text { in } \\
\text { in }\end{array}$ & సี. & $r$ & \\
\hline $\mathrm{SiO}_{2}$ & $\begin{array}{l}\text { ำ } \\
\text { o }\end{array}$ & 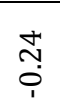 & ஸे & 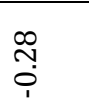 & $\stackrel{\vec{N}}{\stackrel{i}{i}}$ & $\begin{array}{l}0 \\
0 \\
0 \\
1\end{array}$ & $\stackrel{\stackrel{L}{N}}{\stackrel{0}{0}}$ & $\begin{array}{l}0 \\
:\end{array}$ & స̃? & సै: & $\begin{array}{l}\text { Mn } \\
\stackrel{n}{0} \\
\end{array}$ & $\begin{array}{l}0 \\
0 \\
0\end{array}$ & 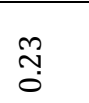 & $\stackrel{\stackrel{\llcorner}{N}}{\circ}$ & $\neg$ \\
\hline
\end{tabular}

Table 4: Correlation Matrix of Physico-Chemical Parameters Studied at the EML.

Values in Bold Are Significantly Different from 0 at a Level Alpha $=0.05$ 
Significant and negative correlations are also observed between Tem and $\mathrm{NO}_{2}^{-}(\mathrm{r}=-0.64)$; EC and $\mathrm{NO}_{2}^{-}(\mathrm{r}=-$ $0.80)$; $\mathrm{DO}$ and $\mathrm{PO}_{4}{ }^{3-}(\mathrm{r}=-0.50) ; \mathrm{NO}_{2}{ }^{-}$and $\mathrm{SiO}_{2}(\mathrm{r}=-0.53)$ and between $\mathrm{NO}_{3}{ }^{-}$and $\mathrm{PO}_{4}{ }^{3-}(\mathrm{r}=-0.50)$. There is not correlation between the nitrogenous compound $\left(\mathrm{NO}_{2}{ }^{-}, \mathrm{NO}_{3}{ }^{-}\right.$and $\mathrm{NH}_{4}{ }^{+}$).

The eigenvalues (Variances) of the correlation matrix, allow to measure the percentage of the expressed variance by each dimension or factorial (Table 5). This table shows that the first three dimensions represent $56.47 \%$ of the total inertia, with $26.02 \%$ for the first dimension (Dim-1), $17.29 \%$ for the second dimension (Dim-2) and $13.16 \%$ for the third dimension (Dim-3). These three dimensions seems to be sufficient to express the essential of this inertia, meaning that, the representation of the data in these three dimensions provides adequate information on the proximity of the elements. Dimensions 1, 2 and 3 thus selected, highlight their correlations with the various studied variables (Table 6). In order to facilitate the understanding of the expressed variability by the dimensions, attention is focused on the variables having a strong contribution to the dimension or to the principal component, as presented in (Fig. $3: 3 a, 3 b$, 3c). The red dashed line on the graph indicates the expected average contribution (threshold contribution).

\begin{tabular}{|c|c|c|c|c|c|c|c|c|}
\hline & Dim-1 & Dim-2 & Dim-3 & Dim-4 & Dim-5 & Dim-6 & Dim-7 & Dim-8 \\
\hline Valeur propre & 3.90 & 2.59 & 1.97 & 1.58 & 1.29 & 1.14 & 0.64 & 0.54 \\
\hline Variabilité (\%) & 26.02 & 17.29 & 13.16 & 10.55 & 8.62 & 7.59 & 4.23 & 3.59 \\
\hline \% cumulé & 26.02 & 43.31 & 56.47 & 67.02 & 75.64 & 83.23 & 87.46 & 91.08 \\
\hline
\end{tabular}

Table 5: Eigenvalues and Percentages of Expressed Variances by Dimensions

For a given dimension, a variable with a contribution above this threshold may be considered important for contributing to the dimension 'STHDA, 2017".

\begin{tabular}{|c|c|c|c|}
\hline Variables & Dim-1 & Dim-2 & Dim-3 \\
\hline Tem & 0.72 & -0.05 & -0.35 \\
\hline pH & 0.44 & 0.12 & 0.19 \\
\hline EC & 0.77 & -0.09 & -0.34 \\
\hline Tur & -0.14 & 0.37 & -0.42 \\
\hline Tra & -0.04 & 0.57 & -0.38 \\
\hline Dep & 0.06 & 0.61 & 0.17 \\
\hline TDS & 0.75 & 0.06 & 0.34 \\
\hline $\mathrm{SS}$ & 0.47 & -0.06 & 0.70 \\
\hline $\mathrm{DO}$ & 0.24 & 0.71 & 0.39 \\
\hline $\mathrm{DOC}$ & -0.68 & -0.41 & -0.06 \\
\hline $\mathrm{NO}_{2}{ }^{-}$ & -0.75 & 0.13 & 0.53 \\
\hline $\mathrm{NO}_{3} \mathrm{NH}_{4}{ }^{-}$ & 0.34 & 0.51 & -0.28 \\
\hline $\mathrm{PO}_{4}{ }^{--}$ & 0.55 & -0.08 & 0.37 \\
\hline $\mathrm{SiO}_{2}$ & 0.25 & -0.76 & 0.12 \\
\hline
\end{tabular}

Table 6: Correlations between Variables and the Main Dimensions

The variables that have a contribution greater than or equal to the expected average contribution are :

- $\quad$ EC (14.95\%), TDS (14.50\%), $\mathrm{NO}_{2}{ }^{-}$(14.28\%), Tem (13.45\%), DOC (11.74\%) et $\mathrm{NH}_{4}{ }^{+}(7.76 \%)$ for the first principal component (Dim-1) ;

- $\quad \mathrm{PO}_{4}{ }^{3-}$ (22.47\%), DO (19.66\%), Dep (14.21\%), Tra (12.34\%), $\mathrm{NO}_{3}{ }^{-}(10.04 \%)$ et $\mathrm{SiO}_{2}(7.36 \%)$ for the second principal component (Dim-2) ;

- $\quad \mathrm{SM}(24.94 \%), \mathrm{NO}_{2}^{-}(14.35 \%)$, Tur (9.07\%), DO (7.89)\%, Tra (7.33\%), et $\mathrm{NH}_{4}^{+}(7.07 \%)$ for the third principal component (Dim-3). 


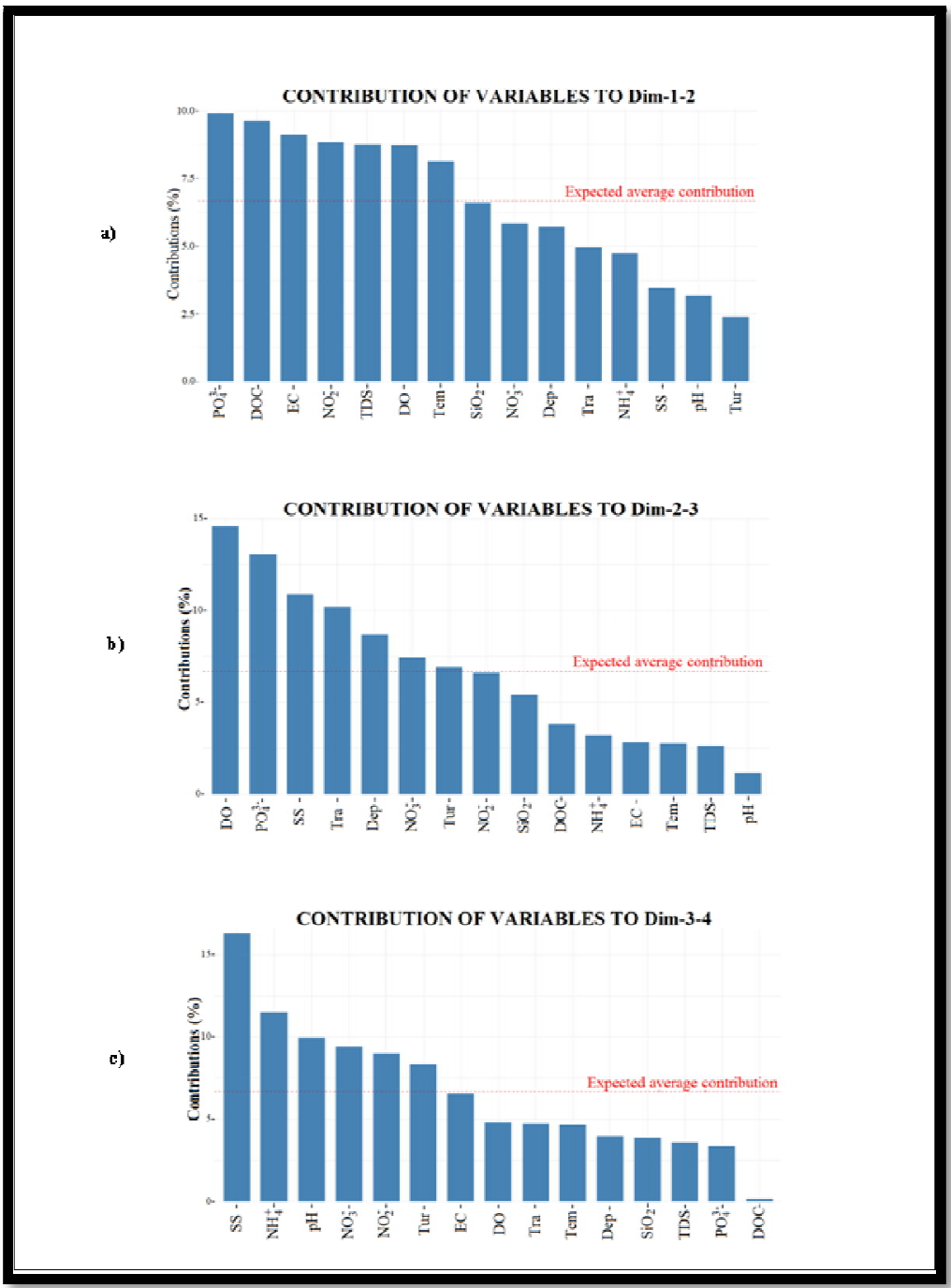

Figure 3: Contributions of Variables to the Three Factorial Planes: a) Dim-1-2,

b) Dim-2-3 and (c) Dim-3-4

The graphs of the Principal Component Analysis (PCA) for variables and for individuals in the three factorial planes (Dim-1-2, Dim-2-3 and Dim-3-4) presented as correlation circles (for variables) and as confidence ellipses (for individuals) highlight groupings, oppositions and directional trends.

For variables, each of the three factorial planes exhibit two poles (Fig. 4, 5, 6) :

- The first principal component (Dim-1), which displays $26.02 \%$ of the expressed variance (Fig. 4), defines an axis of mineralization with an inorganic salts enrichment. It opposes the EC, TDS, Tem, $\mathrm{NH}_{4}{ }^{+}$(variables positively linked to the axis) to $\mathrm{NO}_{2}{ }^{-}$and DOC (variables negatively linked to the axis) ;

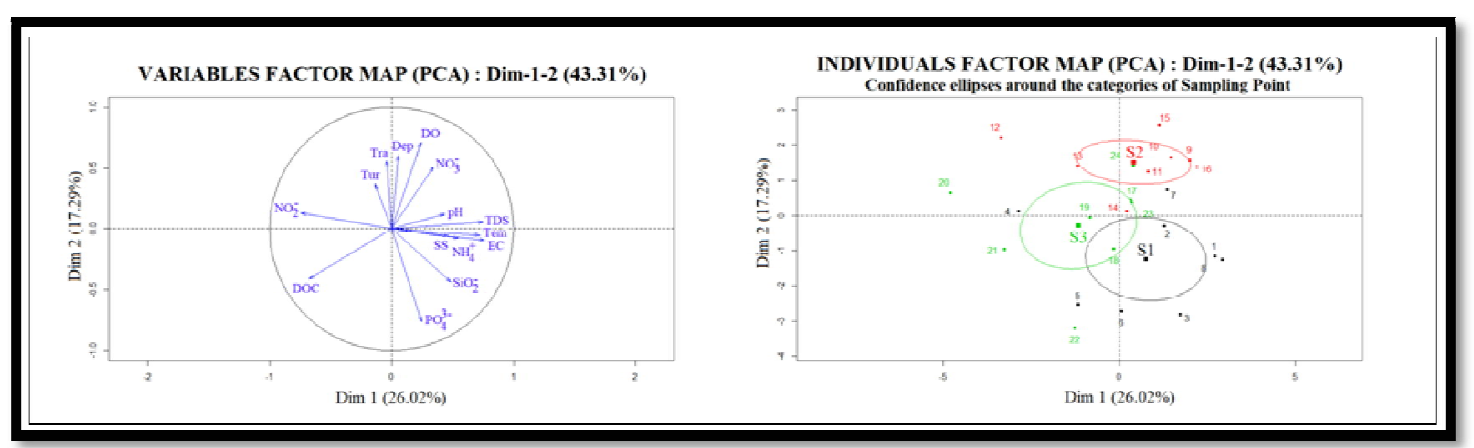

Figure 4: Projection of Variables and Individuals on the First Factorial Plane Dim-1-2

- The second principal component (Dim-2), which represent $17.29 \%$ of the information (Fig. 5), characterizes an erosion axis with organic matters pollution from organic matters. It opposes DO, Dep, Tra and $\mathrm{NO}_{3}{ }^{-}$(variables positively linked to the axis) to $\mathrm{PO}_{4}{ }^{3-}$ and $\mathrm{SiO}_{2}$ (variables negatively linked to the axis) ; 


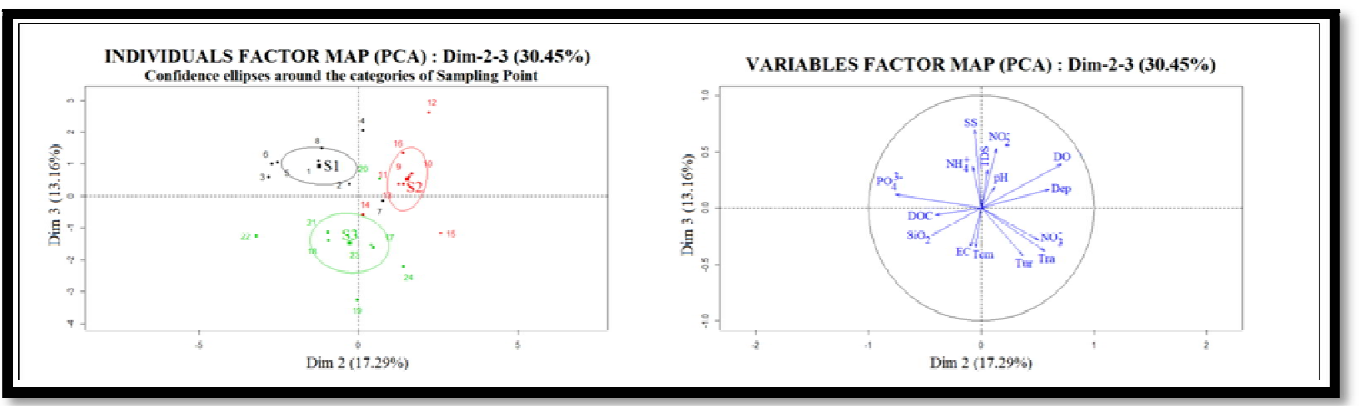

Figure 5: Projection of Variables and Individuals on the Second Factorial Plane Dim-2-3

- The third principal component (Dim-3) which shows $13.16 \%$ of the expressed variance (Fig. 6), reflects an axis of suspended matters enrichment, with more or less turbid waters. It opposes $\mathrm{SM}, \mathrm{NO}_{2}{ }^{-}, \mathrm{DO}$ and $\mathrm{NH}_{4}{ }^{+}$(variables positively linked to the axis), to Tur and Tra (variables negatively linked to the axis).

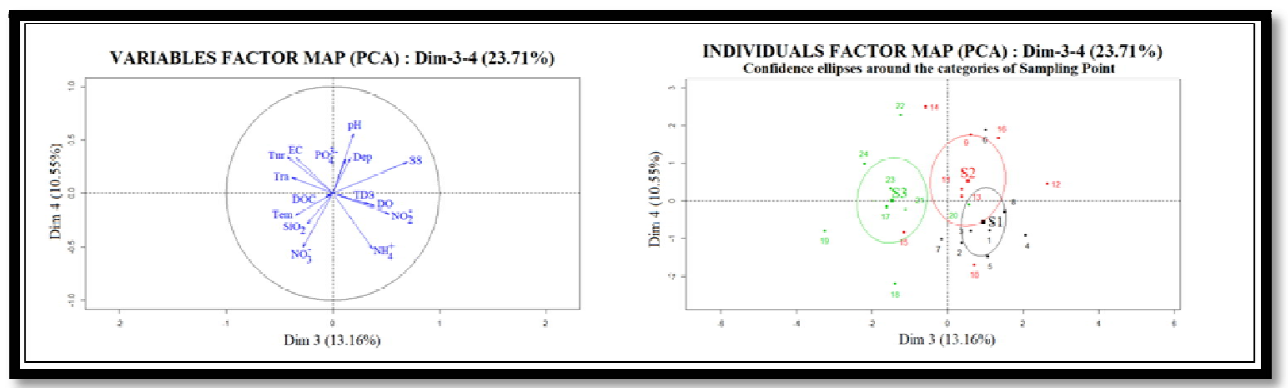

Figure 6: Projection of Variables and Individuals on the Third Factorial Plane Dim-3-4

The projection of individuals in the three factorial planes (Dim-1-2, Dim-2-3 et Dim-3-4) shows that:

- (Dim-1) opposes individuals 15, 10, 9, 16 (having a positive coordinate on the axis) sharing high values for D0, $\mathrm{NO}_{3}{ }^{-}$, Dep and low values DOC ; to individuals 20,12, 21, 4 (having a negative coordinate on the axis) sharing high values for $\mathrm{NO}_{2}{ }^{-}$and low values for EC, Tem, $\mathrm{pH}, \mathrm{SiO} 2$ and TDS. For this main component, the confidence ellipses of the Sampling Point modality, shows that there is no significant difference in the position of the sampling sites S1 and $\mathrm{S} 3$ in the main plane, as these overlap.

- (Dim-2) opposes individuals 6, 5, 3, 22 (having a positive coordinate on the axis) sharing high values for SiO2 and low values for Tra and $\mathrm{NO}_{2}{ }^{-}$; to individuals $4,12,15,24$ (having a negative coordinate on the axis) sharing high values for Tur, OD and low values for $\mathrm{NH}_{4}{ }^{+}$. For this dimension, there is a significant difference in the position of the three sampling sites $(\mathrm{S} 1, \mathrm{~S} 2, \mathrm{~S} 3)$ in the main plane, as there is no overlap between the different confidence ellipses.

- (Dim-3) contrasts individuals $12,4,10$ (with a positive coordinate on the axis) sharing high values for $\mathrm{NO}_{2}{ }^{-}, \mathrm{NH}_{4}{ }^{+}$ and low values for EC; to individuals 24, 19, 18 (with a negative coordinate on the axis) sharing high values for the variable Tur and low values for MES. For this principal component, there is no significant difference in the position of sampling sites $\mathrm{S} 1$ and $\mathrm{S} 2$, as their confidence ellipses overlap.

- The Principal Component Analysis (PCA) of the variables and individuals in the three factorial planes (Dim-1-2, Dim-2-3 and Dim-3-4), allows us to highlight the existence of three distinct typology groups of the EML waters :

- first typology : the group of waters rich in organic matter, indicating anthropogenic pollution and corresponds to the waters of site $\mathrm{S} 1$;

- $\quad$ second typology : the group of mineralized, deep and OD-rich waters, corresponds to the waters of site S2 ; and

- third typology : the group of turbid waters rich in MS, corresponds to the waters of the site S3.

\section{Conclusion}

The Application of Principal Component Analysis (PCA) for the physico-chemical characterization of Ebolowa Municipal Lake (EML) waters has revealed a degradation of the water quality of this hydrosystem. This pollution originates from the input of effluents of anthropic origin discharged by the riverine populations in to the Mfoumou and Bengo'o rivers that feed this water body. PCA identified a typology dominated by three water groups. Sampling sites S1 and S3 are the most affected by pollution, due to their proximity to these two rivers. Sampling site S2, due to its position close to the centre of the lake and far from the two rivers, is characterised by deep water, fairly well oxygenated. The correlation between $\mathrm{NO}_{3}$ - and $\mathrm{PO}_{4}{ }^{3}-(-0.50)$, highlights the anthropogenic origin of the pollution of the LME waters. There is an urgent need to put in place measures to fight against this pollution, as this aquatic ecosystem provides goods and services to the riverine populations (fishing. swimming. eco-tourism...etc), and is a suitable habitat for several flora and fauna communities. Good management of this hydrosystem depends first and foremost on raising the awareness of the people living along the shores of this lake. Constant monitoring of the lake waters should also be considered, the aim here being to regularly assess its pollution level and enable it to increase its resilience. 


\section{Acknowledgment}

The authors would like to thanks the entire PRESS NO\&SW Project team for the training on statistical analysis with R software. Great thanks to the trainer, Miss JOKAM NENKAM Therese Line Laure.

\section{References}

i. Abrid, D. (2015). Caractérisation physico-chimique, minéralogique et géochimique des sédiments de la retenue du barrage Sidi Chahed et des sols du bassin versant de l'oued Mikkés. Thèse Doctorat, Université Moulaya Ismail, Maroc, 233p.

ii. Adjia, G.M., Pial A.C., Ngoupayou J.R.N., \& Akoa A. (2013). Caractérisation hydrologique, morpho-métrique et physico-chimique d'un hydrosystème urbain: le lac municipal d'Ebolowa (Sud-Cameroun). Afrique Science, $09(3), 122-134$.

iii. A.F.N.O.R. (1997). Qualité de l'eau. Recueil des Normes Françaises, Environnement, Tomes (1, 2, 3 \& 4), 1372 p.

iv. A.P.H.A. (1998). Standard methods for the examination of water and wastewater. APHA, AWWA and WEF (Ed., $\left.20^{\text {th }}\right)$, Baltimore, Maryland, USA.

v. Arrignon, J. (1991). Aménagement piscicole des eaux douces. Lavoisier (Ed.), Paris, France, 631p.

vi. Ayadi, I., Habib, H., \& Yasminen D. (4 Septembre 2008) (2008). XIIIth World Water Congress 1. International Water Ressources Association, Montpellier, France.

vii. Ayah, M., Grybos, M., Tampo, L., Bawa, L.M., Bril, H., \& Djaneye, B. (2015). Qualité et pollution des eaux d'un hydrosystème littoral tropical : cas du système lagunaire de Lomé, Togo. European Scientific Journal, 11(15), 95119.

viii. Benchaar, C. (1999). Apport de l'analyse en composantes principales dans l'explication des mécanismes hydrochimiques des oueds Seybouse, Kébir Est et Kébir Ouest (Est Algérien). Mémoire Magister, Université d'Annaba, $177 \mathrm{p}$.

ix. Chapman, D., \& Kimstach, V. (1996). Selection of water quality variables. In Chapman, D. (Ed., 2nd), Water quality assessments - A guide to the use of biota, sediments and water in environment monitoring (pp. 59-126). E\&FN Spon, London.

x. Cunningham, W.P., \& Saigo, B.W. (1997). Environmental Science a Global Concern. WMC Brown Publisher (4th Ed.), New York, 389p.

xi. Djoko, K.R.P. (2007). Evaluation de la qualité des eaux du barrage de la Mopfou à Yaoundé. Physico-chimie et peuplement algal. Mémoire DEA, Université de Yaoundé I, 67 p.

xii. El Oumlouki, K., Moussadek, R., Zouahri, A., Dakak, H., Chati, M., \& El Amrani, M. (2014). Etude de la qualité physico-chimique des eaux et des sols de la région Souss Massa (cas de périmètre Issen, Maroc). Journal of Materials and Environmental Science, 5(2), 2365-2374.

xiii. ERA-Cameroun (2007). Stratégie municipale concertée d'accès à l'eau potable et à l'assainissement de la ville d'Ebolowa. Communauté Urbaine d'Ebolowa, 100 p.

xiv. Ewane, A.I. (2005). Etude de la préfaisabilité du projet d'aménagement du Lac Municipal d'Ebolowa. Mémoire de DESS, Université de Yaoundé I, 60p.

xv. Husson, F., Lê, S., \& Pagès, J. (2009). Analyse des données avec R. Presses Universitaires de Rennes (Ed.), Collection pratique de la statistique, 224p.

xvi. Izydorczyk, K. (2004). How to assess phytoplankton biomass?. In Zalewski, M., \& Wagner-Lotkowska, I. (Ed.), Guidelines for the Integrated Management of the Watersheds. Phytotechnoloy and Ecohydrology (pp. 106-109). Newletter and Technical Publications, Freshwater Management Series, UNEP.

xvii. Kemka, N., Njine, T., Zebaze, T.S.H., Niyitegeka, D., Monkiedje, A., Foto, M.S., Nola, M., \& Compère, P. (2003). Quantitative importance of Cyanobacteria populations in a hypertrophic shallow lake in the sub-equatorial African region (Yaounde Municipal Lake, Cameroon). Arch fur Hydrobiologie, 983, 1-16.

xviii. Lê, S., Josse, J. \& Husson, F. (2008). FactoMineR: An R package for Multivariate Analysis. Journal of Statistical Software, 25(1), 1-18.

xix. $\quad$ Lgourna, Z., Warner, N., Bouchaou, L., Boutaleb, S., Tagma, T., Hssaisoune, M., Ettayfi N., \& Vengosh, A. (2014). Nitrate contamination of alluvial groundwater in the Ziz basin. Southeastern Morocco. Moroccan Journal of Chemistry, 2(5), 447-451.

xx. Madjiki, A.G. (2013). Etude écohydrologique du Lac Municipal d'Ebolowa : cas du niveau d'eutrophisation et du peuplement phytoplanctonique. Mémoire MASTER, Université de Yaoundé I, 91 p.

xxi. Mouissi, S. \& Alayat, H. (2016). Utilisation de l'Analyse en Composantes Principales (ACP) pour la Caractérisation Physico-Chimique des Eaux d'un Ecosystème Aquatique : Cas du Lac Oubéira (Extrême NE Algérien). Journal of Materials and Environmental Science, 7 (6), 2214-2220.

xxii. Njine, T., Kemka, N., Zebaze, T.S.H., Nola, M., Niyitegeka, D., Ayissi, E.T.P., \& Foto, M.S. (2007). Peuplement phytoplanctonique et qualité des eaux en milieu lacustre anthropisé : cas du lac municipal de Yaoundé (Cameroun). African Journal of Science and Technology, Science and Engineering Series, 8(1): 39-51.

xxiii. Reggam, A., Bouchelaghem, H., \& Houhamdi M. (2015). Qualité Physico-Chimique des Eaux de l'Oued Seybouse (Nord-Est de l'Algérie) : Caractérisation et Analyse en Composantes Principales. Journal of Materials and Environmental Science, 6(5), 1417-1425.

xxiv. Ridhi, S., \& Garg, J.K. (2015). Surface water quality assessment of Bhindawas lake (Haryana, India) using Multivariate statistical techniques. Journal of Global Ecology and Environment, 2(1), 34-46.

xxv. Rodier, J. (2009). Analyse de l'eau : eaux naturelles, eaux résiduaires, eau de mer. Dunod (Ed., 9th), Paris, 1579 p. 
xxvi. STHDA (2017). Principal Component Methods in R: Practical guide. PCA - Principal Component Analysis Essentials. Statistical Tools for High-Throughput Data Analysis, Online article.

xxvii. Stodddard, J.L., Jeffries, D.S., Lukewille, A., Clair, T.A., Dillon, P.J., Driscoll, C.T., Forsius, M., Johannessen, M., Kahl, J.S., Kellogg, J.H., Kemp, A., Mannio, J., Monteith, D.T., Murdoch, P.S., Skielkvale, B.L., Staiton, M.P., Traaen, T., Van Dam, H.,Webster, K.E., \& Wilander, A. (1999). Regional trends in aquatic recovery from acidification in North and Europe. Nature, 401, 575-578.

xxviii. Wetzel, R.G. (1983). Limnology. Saunders College Publishing (Ed., 2 ${ }^{\text {nd }}$ ), Philadelphia, New York.

xxix. Zalewski, M., \& Wagner-Lotkowska, I. (Ed.). (2002). Guidelines for the Integrated Management of the Watersheds. Phytotechnoloy and Ecohydrology. Newletter and Technical Publications, Freshwater Management Series, UNEP, 237 p.

xxx. Zohary, T., Pais-Madeira, A.M., Robarts, R., \& Hambright K.D. (1996). Interannual phytoplankton dynamics of a hypertrophic African lake. Archiv fur Hydrobiologie, 136, 105-126. 